\title{
Epigenetic alteration of the donor cells does not recapitulate the reprogramming of DNA methylation in cloned embryos
}

\author{
Gabbine Wee ${ }^{1}$, Jung-Jae Shim ${ }^{1}$, Deog-Bon Koo ${ }^{3}$, Jung-II Chae ${ }^{3}$, Kyung-Kwang Lee ${ }^{3}$ \\ and Yong-Mahn $\operatorname{Han}^{1,2}$ \\ ${ }^{1}$ Department of Biological Sciences, Korea Advanced Institute of Science and Technology (KAIST), 373-1 Guseong- \\ dong, Yuseong-gu, Daejeon 305-701, Republic of Korea, ${ }^{2}$ Korea Advanced Institute of Science and Technology (KAIST), \\ Center for Stem Cell Differentiation, Daejeon 305-701, Republic of Korea and ${ }^{3}$ Korea Research Institute of Bioscience \\ and Biotechnology (KRIBB), Center for Development and Differentiation, Daejeon 305-806, Republic of Korea
}

Correspondence should be addressed to Y-M Han; Email: ymhan@kaist.ac.kr

\begin{abstract}
Epigenetic reprogramming is a prerequisite process during mammalian development that is aberrant in cloned embryos. However, mechanisms that evolve abnormal epigenetic reprogramming during preimplantation development are unclear. To trace the molecular event of an epigenetic mark such as DNA methylation, bovine fibroblasts were epigenetically altered by treatment with trichostatin A (TSA) and then individually transferred into enucleated bovine oocytes. In the TSA-treated cells, expression levels of histone deacetylases and DNA methyltransferases were reduced, but the expression level of histone acetyltransferases such as Tip60 and histone acetyltransferase 1 (HAT1) did not change compared with normal cells. DNA methylation levels of non-treated (normal) and TSA-treated cells were 64.0 and $48.9 \%$ in the satellite I sequence $(P<0.05)$ respectively, and 71.6 and $61.9 \%$ in the $\alpha$-satellite sequence respectively. DNA methylation levels of nuclear transfer (NT) and TSA-NT blastocysts in the satellite I sequence were 67.2 and $42.2 \%(P<0.05)$ respectively, which was approximately similar to those of normal and TSA-treated cells. In the $\alpha$-satellite sequence, NT and TSA-NT embryos were substantially demethylated at the blastocyst stage as IVF-derived embryos were demethylated. The in vitro developmental rate (46.6\%) of TSA-NT embryos that were individually transferred with TSA-treated cells was higher than that $(31.7 \%)$ of NT embryos with non-treated cells $(P<0.05)$. Our findings suggest that the chromatin of a donor cell is unyielding to the reprogramming of DNA methylation during preimplantation development, and that alteration of the epigenetic state of donor cells may improve in vitro developmental competence of cloned embryos.

Reproduction (2007) 134 781-787
\end{abstract}

\section{Introduction}

Clone animals derived from somatic cells indicate that the chromatin of differentiated somatic cells should be reprogrammed to totipotent or pluripotent states by adapting to the ooplasmic microenvironment (Wilmut et al. 1997, Wakayama et al. 1998). However, there are several developmental anomalies including high abortion rate and death shortly after birth (Tanaka et al. 2001, Ogonuki et al. 2002, Tamashiro et al. 2002). For these reasons, it is persuasive that aberrant epigenetic reprogramming of the cloned embryo is responsible for the developmental failures of cloned embryos. Reprogramming of the parental genome or chromatin of somatic cells can be monitored by investigating the profile of epigenetic marks such as DNA methylation. During early embryonic development, zygotic chromatin undergoes genome-wide reprogramming of DNA methylation to acquire developmental competence. The active demethylation of the paternal genome occurs after fertilization and before the first cell division (Mayer et al. 2000, Santos et al. 2002). The maternal genome maintains its DNA methylation status at the pronuclear stage and thereafter its genome-wide demethylation occurs progressively by a passive demethylation mechanism (Monk et al. 1987, Rougier et al. 1998). However, it is likely that the reprogramming of DNA methylation takes place independently on distinct genomic regions by different mechanisms (Kim et al. 2004). In normal bovine embryos, de novo DNA methylation begins at the 8- to 16-cell stage and higher DNA methylation status is detected in the inner cell mass of the blastocyst (Dean et al. 2001), whereas cloned embryos represent incomplete reprogramming of DNA methylation during preimplantation development (Bourc'his etal. 2001, Dean et al. 2001, Kang et al. 2001). In mouse embryos, aberrant DNA methylation patterns are related to the failure of blastocyst formation and pregnancy (Shi \& Haaf 2002). This result clearly demonstrates that DNA methylation status of the early stage embryo might be essential for appropriate gene expression and normal development. 
Recently, we also found that acetylation reprogramming of histone $\mathrm{H} 4$ at lysine 5 is abnormal in early cloned embryos, thereby leading to aberrant transcriptional expression of some imprinted genes (Wee et al. 2006). Further observations on epigenetic behaviors of the donor cell nuclei may contribute to our understanding of the molecular mechanism of cloned embryos. To test whether the epigenetic alteration of somatic cells influences epigenetic reprogramming of cloned embryos, donor cells treated with trichostatin A (TSA) were individually transferred into enucleated oocytes and then DNA methylation status was measured at the blastocyst stage. DNA methylation levels in the satellite I sequence were reduced in the TSA-treated cells and thereafter maintained at the same level in cloned blastocysts. Thus, the chromatin of donor cells seems to be refractory to the reprogramming of DNA methylation during early development. In addition, cloned embryos with TSA-treated nuclei showed a higher developmental competence than those with normal somatic nuclei. This result indicates that epigenetic status of the somatic cell might influence developmental potential of cloned embryos.

\section{Results}

\section{Treatment of donor cells with TSA}

Prior to NT, we first investigated whether TSA treatment induced abnormality of bovine ear skin fibroblasts (bESFs). The cells changed morphologically at $24 \mathrm{~h}$ after TSA treatment. Although TSA-treated cells enlarged in size, flattened and were vague in outlines (Fig. 1A), they had normal karyotypes (Fig. 1B). The cells grew slightly by $12 \mathrm{~h}$ after TSA treatment and thereafter their growth was arrested, whereas normal cells continuously proliferated by $60 \mathrm{~h}$ (Fig. 1C). Thus, TSA treatment inhibited proliferation of bovine fibroblasts. TSA-treated cells showed reduced proportion of the $S$ phase $(P<0.05)$ and enhanced proportion of the G1/G2/M phases compared with non-treated cells (Fig. 1D).
A

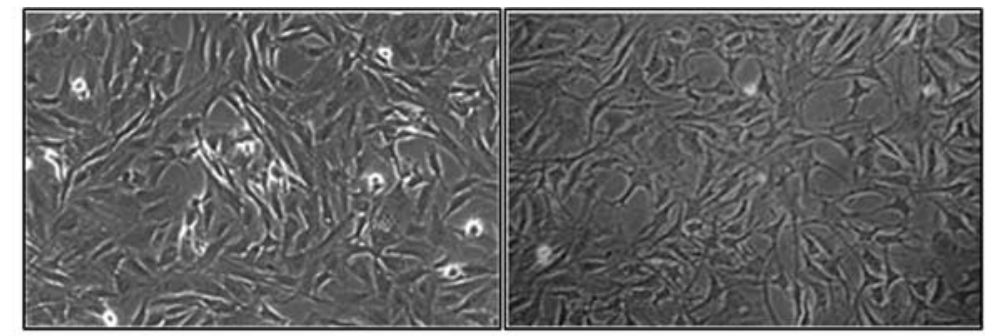

B

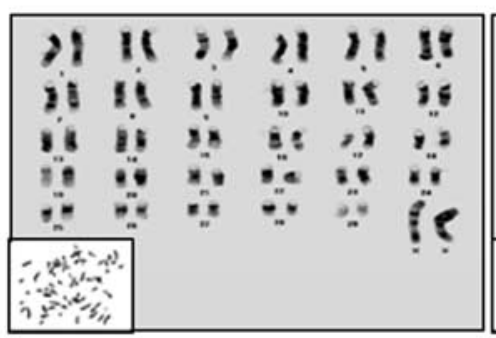

TSA-treated

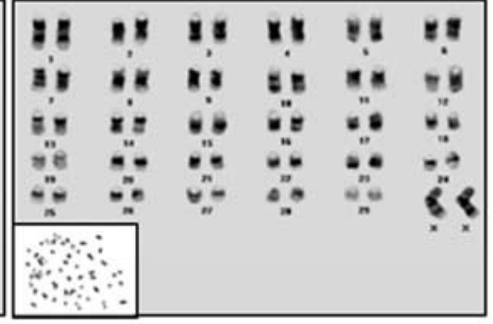

C

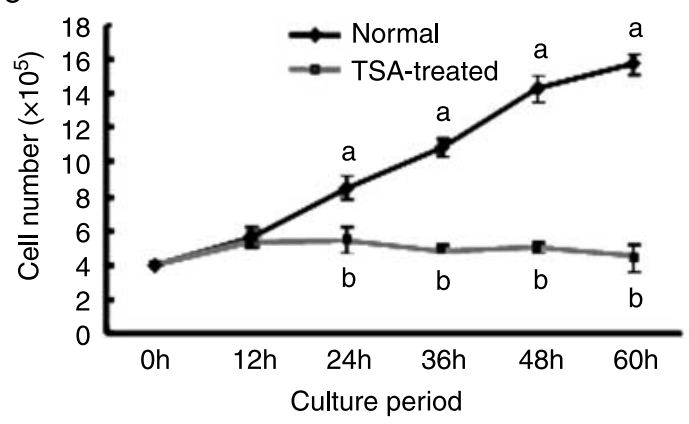

D

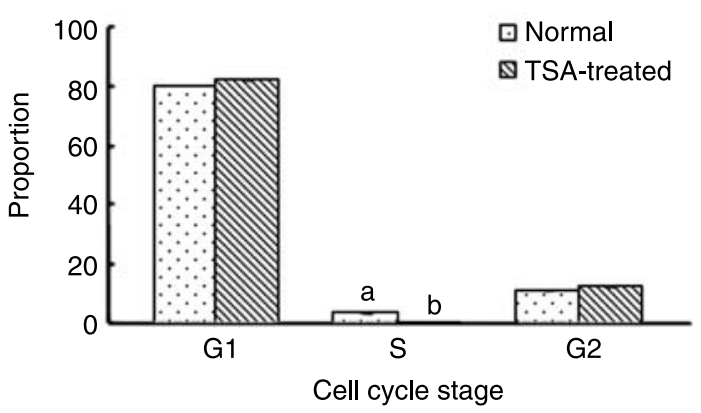

Figure 1 Characterization of TSA-treated bESF cells. (A) Morphology of TSA-treated cells. (B) Karyotype of TSA-treated cells. (C) Proliferation of TSAtreated cells. (D) Distribution of TSA-treated cells to the cell cycle stages. Each value is expressed as mean \pm s.E.M. ${ }^{\text {a,b }}$ Different superscripts denote significant differences between experimental groups $(P<0.05)$. Experiments for the cell cycle analysis were repeated thrice. 


\section{Expression of enzymes involved in epigenetic modification in TSA-treated cells}

The following experiment was performed to determine whether TSA treatment affects expression of enzymes involved in epigenetic modification in bovine cells. Most TSA-treated cells had weak immunofluorescence signals for HDAC2 and Dnmt1 when compared with non-treated cells (Fig. $2 \mathrm{~A}$ and $\mathrm{B}, P<0.05$ ). Histone acetyltransferases such as Tip60 and HAT1 were consistently expressed in TSA-treated cells, whereas expression of histone deacetylases (HDAC1 and HDAC2) and DNA methyltransferases (Dnmt1, Dnmt3a, Dnmt3b, and Dnmt3L) was decreased (Fig. 2C). Interestingly, expression of Dnmt1 was remarkably reduced after TSA treatment, indicating that expression of Dnmt1 might be more sensitive to the activity of HDACs than other Dnmts.

\section{Reprogramming of DNA methylation in TSA-NT embryos}

To monitor epigenetic behaviors of donor cell nuclei, the DNA methylation state of TSA-NT (nuclear transferred with TSA-treated cells) embryos was compared with that of NT embryos (nuclear transferred with non-treated cells). In the bovine satellite I sequence, the DNA methylation level (48.8\%, 99/203 CpG sites) of TSA-treated cells was significantly lower than that $(64.0 \%, 146 / 228 \mathrm{CpG}$ sites) of non-treated cells (Fig. 3A, $P<0.05$ ). DNA methylation levels of IVF, NT, and TSA-NT blastocysts were $28.9 \%$ (59/204 CpG sites), 67.2\% (137/204 CpG sites), and $42.2 \%$ (86/204 CpG sites) respectively (Fig. 3B). Intriguingly, DNA methylation levels of NT and TSA-NT embryos were approximately similar to those of their respective donor cells. These results suggest that the satellite I region of somatic cell nuclei is unyielding to the reprogramming of DNA methylation in cloned embryos during preimplantation development. As shown in Fig. 4A, the DNA methylation level $(61.9 \%, 78 / 126 \mathrm{CpG}$ sites) of the $\alpha$-satellite sequence in TSA-treated cells was slightly reduced compared with non-treated cells $(71.4 \%$, 75/105 CpG sites). DNA methylation levels of IVF, NT, and TSA-NT embryos in the $\alpha$-satellite sequence were $32.4 \%$ (35/108 CpG sites), 33.3\% (24/72 CpG sites), and $38.9 \%$ (28/72 CpG sites) respectively (Fig. 4B). Thus, CpG sites in the $\alpha$-satellite sequence of somatic cell nuclei are vulnerable to be demethylated in cloned embryos.

\section{Improved preimplantation development of TSA-NT embryos}

After somatic cell NT, in vitro developmental competence of cloned bovine embryos with TSA-treated cells was investigated (Table 1). TSA-treated cells were individually transferred into single enucleated oocytes. Reconstructed oocytes were cultured in vitro for 7 days. At day 3 of in vitro culture, cleavage rates of IVF, NT, and
TSA-NT embryos to four- to eight-cell stages were $85.9 \%$ $(146 / 170), 80.2 \%(162 / 202)$ and $79.6 \%(164 / 206)$ respectively. Thus, there was no difference in the cleavage rate among the experimental groups. However, in vitro developmental rates $(46.6 \%, 48 / 170)$ of TSA-NT embryos to blastocysts were significantly higher $(P<0.05)$ than those of IVF and NT embryos $(28.2 \%$, $64 / 202$ and $31.7 \%, 96 / 206$ respectively).

\section{Discussion}

Differentiated somatic cell nuclei with highly methylated state appear to be incompletely reprogramed in cloned embryos during preimplantation development. In fact, aberrant reprogramming of DNA methylation in early cloned embryos has been reported (Bourc'his et al. 2001, Dean et al. 2001, Kang et al. 2001, 2002). In this study, we demonstrate that the somatic cell nuclei epigenetically altered by treatment with a chemical reagent are still refractory to the epigenetic reprogramming in cloned embryos.

Epigenetic alteration of donor cells could be induced by inhibiting activities of epigenetic-modifying enzymes such as histone acetyltransferases, HDACs, and Dnmts. TSA, which inhibits the activity of HDACs by chelating of zinc atoms within their catalytic sites (Imai et al. 2000, Finnin et al. 2001), could alleviate transcriptional repression by facilitating chromatin remodeling and relieving methylated CpG sites (Jones et al. 1998, Nan et al. 1998). To modify the epigenetic state of donor cells, in this study, bovine fibroblasts were treated with TSA for $60 \mathrm{~h}$. In TSA-treated cells, expression levels of HDACs and Dnmts were extremely decreased compared with non-treated cells (Fig. 2C). Interestingly, there was no significant reduction in the expression of acetyltransferases such as HAT1 and Tip60. In contrast to non-treated cells, which were acetylated in the interphase and deacetylated in the metaphase, TSA-treated cells were highly acetylated throughout the cell cycle (Wee et al. 2006). The results obtained in this study indicate that hyperacetylation of TSA-treated cells might be due to the decreased expression of HDACs, but not responsible for the consistent expression of histone acetyltransferases. Thus, the epigenetic status of donor cells could be altered by regulating the activity of epigenetic-modifying enzymes.

From our results that the expression of Dnmts was suppressed (Fig. 2C), we could also expect low DNA methylation levels of TSA-treated cells. In fact, TSAtreated cells showed a lower DNA methylation level than non-treated cells on two repetitive sequences (Figs $3 \mathrm{~A}$ and $4 \mathrm{~A}$ ). Inhibitors of the HDAC resulted in global or regional DNA demethylation in various cell lines (Szyfet al. 1985, Selker 1998, Hu et al. 2000). After somatic cell NT, TSA-NT embryos showed a lower DNA methylation level in the satellite I sequence than NT embryos (Fig. 3B). However, there was no difference 
A

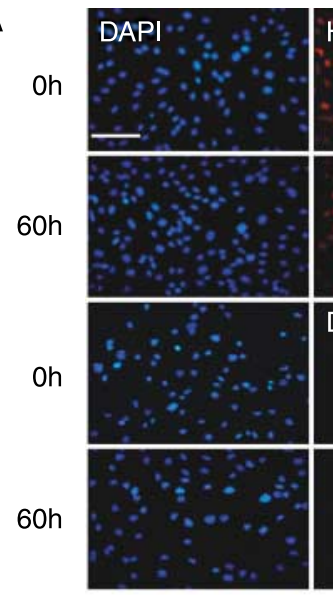

B
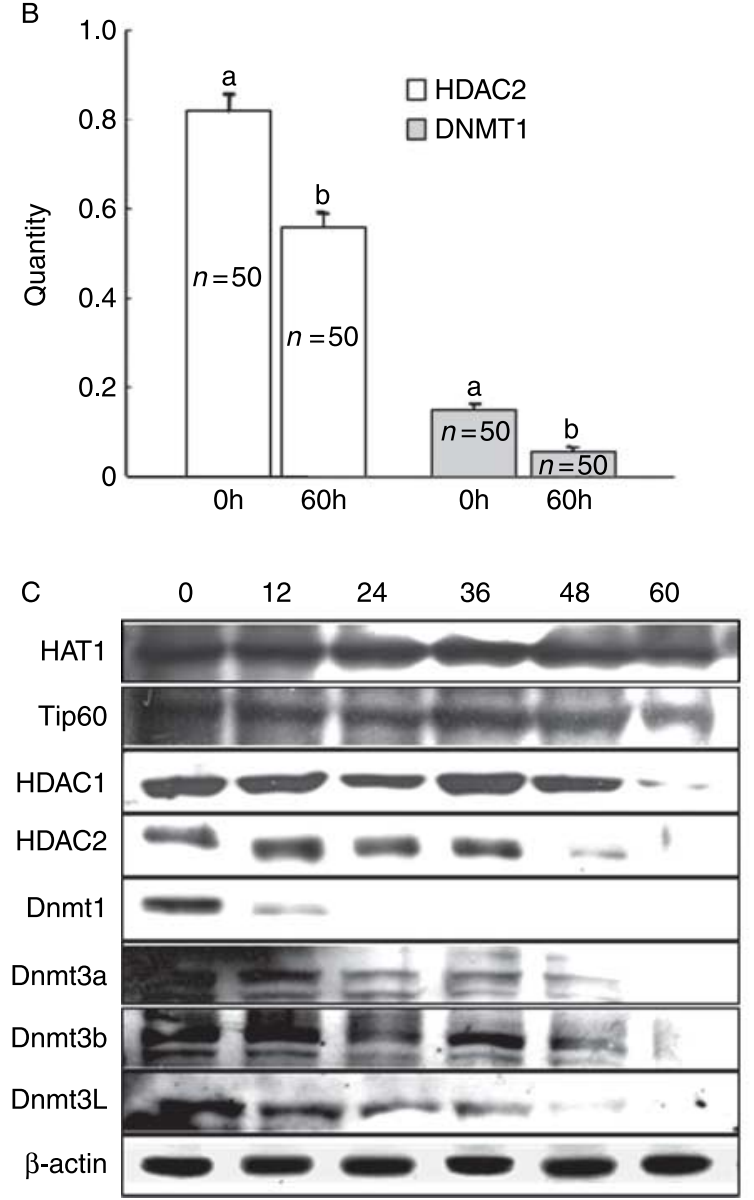

Figure 2 Expression of epigenetic-modifying enzymes in TSA-treated cells. (A) Intensity of HDAC2 and Dnmt1 signals in non- and TSA-treated cells. Scale bar, $50 \mu \mathrm{m}$ (B) Comparison of signal intensity quantified by the ratio of HDAC2/DNA or Dnmt1/DNA signals. The quantitative value is expressed as mean \pm s.E.M. ${ }^{\text {a,b }}$ Different superscripts denote significant differences between experimental groups $(P<0.05)$. (C) Western blot analysis for epigenetic-modifying enzymes in TSA-treated cells. in DNA methylation levels between donor cells and cloned embryos. The satellite I sequence did not seem to be reprogrammed in cloned embryos during early development (Kang et al. 2005). Intriguingly, the lower DNA methylation level of TSA-treated cells was maintained at a similar level on the satellite I sequence by the blastocyst stage after somatic cell NT. This result suggests that epigenetic alteration of somatic cell nuclei does not affect reprogramming of DNA methylation in the repetitive sequence during early development of cloned embryos. In contrast to the satellite I sequence, the $\alpha$-satellite sequence was sustantially demethylated even in NT and TSA-NT embryos (Fig. 4B). We previously reported that the $\boldsymbol{\alpha}$-satellite sequence was passively demethylated in IVF and NT bovine embryos (Kang et al. 2005). Our findings show that reprogramming of DNA methylation takes place in the $\alpha$-satellite sequence of cloned embryos. Based on the results of two repetitive sequences examined in this study, it is conceivable that reprogramming of DNA methylation might act separately on the respective genomic regions during early development. In fact, three repetitive sequences showed differential reprogramming patterns of DNA methylation during preimplantation development of mouse embryos (Kim et al. 2004).

Various epigenetic events, such as active demethylation, passive demethylation, and de novo methylation, are crucial for normal embryo development (Reik \& Dean 2001, Li 2002). In this study, we also examined whether altered epigenetic states of donor cells might influence developmental competence of cloned embryos. We found that reconstructed oocytes with TSA-treated donor cells showed a higher in vitro developmental rate than IVF and NT embryos (Table 1). This result is consistent with a previous report that TSA treatment of donor cells could improve in vitro development of cloned bovine embryos (Enright et al. 2003). This improved development might be explained by the fact that TSA treatment enhanced expression of embryonic genes by altering epigenetic states of donor cell nuclei. When mouse embryos were incubated in TSA, expression of the transgene and the endogenous genes was significantly increased at the preimplantation stages (Thompson et al. 1995, Aoki et al. 1997). Moreover, TSA treatment in activation medium enhanced blastocyst formation of cloned mouse embryos up to fivefold and reduced abnormality of clones (Kishigami et al. 2006). However, they did not show the results about reprogramming of DNA methylation in cloned embryos. From our results, it is likely that improved development of TSA-NT embryos might be responsible for epigenetic alleviation of donor nuclei such as lower DNA methylation. Thus, this study provides an insight that the developmental competence of cloned embryos could be enhanced by altering epigenetic status of somatic cell nuclei such as DNA methylation. 


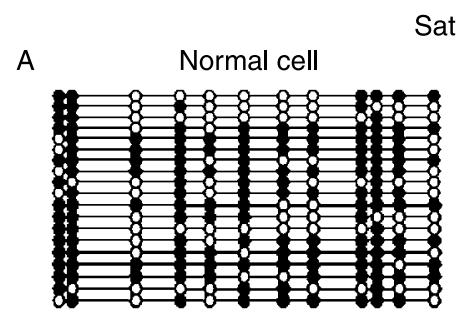

$64.0 \%(146 / 228)$
Satellite I

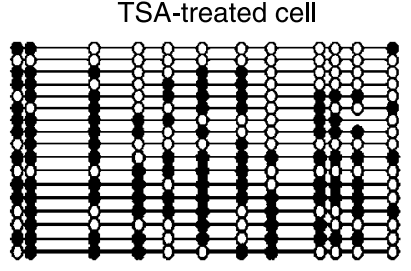

$48.8 \%(99 / 203)$
B

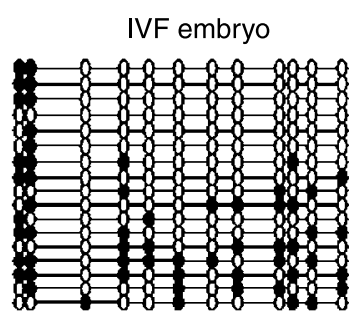

$28.9 \%(59 / 204)$

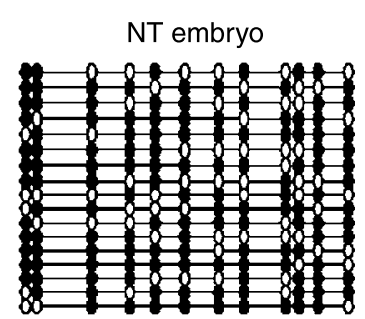

$67.2 \%(137 / 204)$

\section{Materials and Methods}

\section{Cell culture and TSA treatment}

Bovine ear skin fibroblasts (bESFs) were derived from an adult cow aged 3.5 years and cultured in Dulbecco's modified Eagle's medium (GibcoBRL) supplemented with $10 \%$ fetal bovine serum (FBS), $100 \mu \mathrm{M}$ non-essential amino acid (GibcoBRL) and $500 \mu \mathrm{g} / \mathrm{ml}$ gentamycin sulfate (GibcoBRL) at $37^{\circ} \mathrm{C}$ in $5 \% \mathrm{CO}_{2}$ in air. bESF cells were seeded at a concentration of $7 \times 10^{4}$ cells per well on a 24-well culture plate or $1 \times 10^{6}$ cells on a $100 \mathrm{~mm}$ culture dish. After $24 \mathrm{~h}$ of culture, the cells were incubated in the culture medium containing $1 \mu \mathrm{M}$ TSA (Sigma) for $60 \mathrm{~h}$. TSA-treated cells were obtained at intervals of $12 \mathrm{~h}$ and subjected to subsequent experiments.

\section{Karyotype}

At $60 \mathrm{~h}$ after TSA treatment, the karyotype of bESF cells was performed by G-banding analysis. The cells were cultured in
TSA-NT embryo

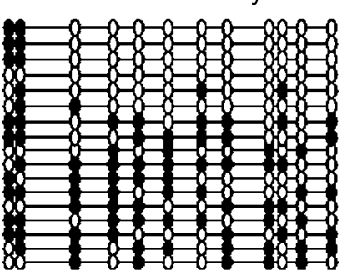

$42.2 \%(86 / 204)$
Figure 3 Analysis of DNA methylation status on the satellite I sequences. (A) DNA methylation levels of non-treated and TSA-treated cells. (B) DNA methylation levels of IVF, NT and TSA-NT blastocysts. culture medium containing $0.1 \mu \mathrm{g} / \mathrm{ml}$ colcemid for $60 \mathrm{~h}$. After trypsinization $(0.25 \%$ trypsin-EDTA), recovered cells were suspended and treated with hypotonic solution of $0.56 \% \mathrm{KCl}$ for $30 \mathrm{~min}$ at room temperature. Fixative solution (methanol:acetic acid $=3: 1$ ) was added to the cells and centrifuged at $700 \mathrm{~g}$ (1000 r.p.m.) for $5 \mathrm{~min}$. The fixative process was repeated twice. The cell pellet was suspended in $1 \mathrm{ml}$ fixative solution and was dropped onto the slide to get metaphase spreads. The slides were immersed in $0.5 \%$ barium hydroxide solution for $3 \mathrm{~min}$ and were incubated in $2 \times \mathrm{SSC}(30 \mathrm{mM} \mathrm{NaCl}$ and $30 \mathrm{mM}$ trisodium citrate) for $2 \mathrm{~h}$ at $50{ }^{\circ} \mathrm{C}$. Then, the samples were stained with $0.1 \%$ Giemsa (Fluka, Gallen, Switzerland) for $30 \mathrm{~min}$, washed thrice with distilled water, and dried in air. The metaphase chromosomes were observed at $400 \times$ magnification under a microscope (Olympus, Tokyo, Japan).

\section{Analysis of cell cycle}

DNA contents of the cells were determined by measuring the fluorescence in a FACScan (BD Science, San Jose, CA, USA) after
A

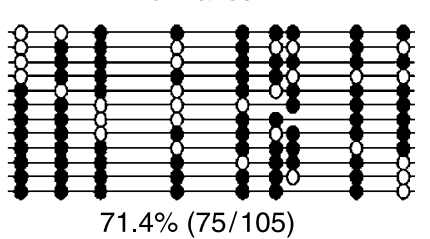

TSA-treated cell

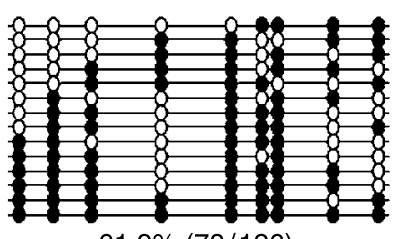

$61.9 \%(78 / 126)$

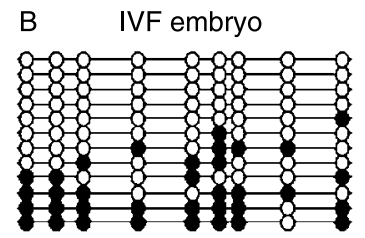

$32.4 \%(35 / 108)$

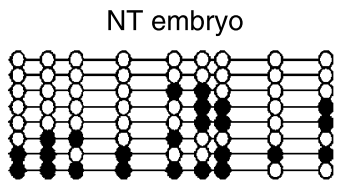

$33.3 \%(24 / 72)$

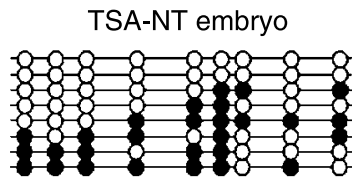

$38.9 \%(28 / 72)$
Figure 4 DNA methylation analysis on the $\alpha$-satellite sequences. (A) DNA methylation levels of non- and TSA-treated cells. (B) DNA methylation levels of IVF, NT and TSA-NT blastocysts. 
Table 1 In vitro development of cloned embryos.

\begin{tabular}{lccc}
\hline Group & $\begin{array}{c}\text { No. of embryos } \\
\text { cultured }\end{array}$ & $\begin{array}{c}\text { No. }(\%) \text { of } \\
\text { embryos } \\
\text { cleaved }\end{array}$ & $\begin{array}{c}\text { No. }(\%) \text { of } \\
\text { blastocysts }\end{array}$ \\
\hline IVF & 170 & $146(85.9)$ & $48(28.2)^{*}$ \\
NT & 202 & $162(80.2)$ & $64(31.7)^{*}$ \\
TSA-NT & 206 & $164(79.6)$ & $96(46.6)^{+}$ \\
\hline
\end{tabular}

These experiments were contemporaneously carried out five times.

${ }^{*,+}$ Different superscripts denote significant differences $(P<0.05)$.

${ }^{a}$ Developmental rate $=$ No. of blastocysts/No. of embryos cultured $\times 100$.

staining with propidium iodide (Sigma). Briefly, the cells were fixed in ice-cold $70 \%$ ethanol for $1 \mathrm{~h}$ and then placed in a solution containing $1 \mathrm{mg} / \mathrm{ml}$ RNase (Sigma) and $20 \mu \mathrm{g} / \mathrm{ml}$ propidium iodide for $30 \mathrm{~min}$. Approximately 10000 cells were measured by a FACScan and proportion of the cells to G0/G1, S, and G2/M phases was determined by the manufacturer's protocol.

\section{In vitro maturation, fertilization and culture of bovine oocytes}

Bovine oocytes were matured and fertilized in vitro as previously described (Koo et al. 2002). Cumulus-oocytes were incubated in maturation medium at $38.5{ }^{\circ} \mathrm{C}, 5 \% \mathrm{CO}_{2}$ in air for $20 \mathrm{~h}$. After maturation, oocytes were fertilized with frozen-thawed sperm and were cultured in CR1 aa medium supplemented with $0.3 \%$ BSA (Sigma) for 3 days. Cleaved embryos were further cultured in each drop $(50 \mu \mathrm{l})$ of CR1aa supplemented with $10 \%$ FBS for 4 days. At day 7 of culture, blastocyst formation was observed.

\section{Somatic cell nuclear transfer (NT)}

Somatic cell NT was carried out as previously described (Wee et al. 2006). Donor cells were individually inserted into the perivitelline space of single enucleated oocytes, and fused by a single direct pulse of $1.6 \mathrm{kV} / \mathrm{cm}$ for $20 \mu \mathrm{s}$ using Electro Cell Manipulator 2001 (BTX, San Diego, CA, USA). At $2 \mathrm{~h}$ after electrofusion, fused embryos were activated with $5 \mu \mathrm{M}$ ionomycin (Sigma) for 5 min followed by treatment with $2.5 \mathrm{mM}$ 6-dimethylaminopurine (Sigma) for $4 \mathrm{~h}$. Reconstructed eggs were cultured in vitro for 7 days in the same culture conditions as described previously.

\section{Immunostaining}

Bovine fibroblasts were fixed in 4\% formaldehyde in PBS for $1 \mathrm{~h}$, washed in PBS containing $0.1 \%$ Tween 20 (TPBS) for $1 \mathrm{~h}$, and then permeabilized with $0.5 \%$ Triton X-100 in PBS for $2 \mathrm{~h}$. The cells were blocked with $1 \%$ BSA in TPBS for $2 \mathrm{~h}$. Primary antibodies were diluted with PBS (1:50) and were co-incubated with samples for $3 \mathrm{~h}$ at $4{ }^{\circ} \mathrm{C}$. After washing for $3 \mathrm{~h}$ in TPBS, the samples were incubated for $30 \mathrm{~min}$ in the presence of Cy3-anti-rabbit immunoglobulin G (IgG; Molecular Probes, Eugene, OR, USA) and then washed in TPBS for $1 \mathrm{~h}$. Samples were mounted on slides with a $90 \%$ glycerol-PBS containing $1 \mathrm{fg} / \mathrm{ml}$ 4,6-diamidino2-phenylindole (DAPI; Molecular Probes). The specific antibodies for histone deacetylase 2 (HDAC2; cat. no. sc-7899; Santa Cruz Biotechnology, Santa Cruz, CA, USA) and DNA methyltransferase 1 (Dnmt1; cat. no. sc-60B1220; Santa Cruz Biotechnology) were used in this experiment. Fluorescent images were observed on an epifluorescence light microscope (Olympus). Exposure times of fluorescent light were kept constant for the respective channel (Cy3 or DAPI). Quantification of images was determined by the ratio of a primary antibody signal to a DAPI DNA signal using an image analyzer system, SigmaScan-pro V5.01 (SPSS Inc., Chicago, IL, USA). The images were merged using Adobe Photoshop 6.0 software.

\section{Western blot}

Cells $\left(\sim 1 \times 10^{7}\right.$ cells) were washed twice with PBS and lysed with 10 volume of lysis buffer on ice for $1 \mathrm{~h}$. The lysis buffer consists of $25 \mathrm{mM}$ HEPES (pH 7.8), $25 \mathrm{mM} \mathrm{KCl}, 5 \mathrm{mM} \mathrm{MgCl}$, $0.05 \mathrm{mM}$ EDTA, $10 \%$ glycerol, $0.1 \%$ NP40, $0.1 \mathrm{mM}$ phenylmethylsulphonyl fluoride (PMSF), and $1 \mathrm{mM}$ dithiothreitol (DTT). The nuclear pellet was washed with lysis buffer to remove cytoplasmic contaminants, resuspended in nuclear extract buffer, and then incubated at $4{ }^{\circ} \mathrm{C}$ for $30 \mathrm{~min}$. The nuclear extract buffer consists of $10 \mathrm{mM} \mathrm{HEPES} \mathrm{(pH} \mathrm{7.5),} 200 \mathrm{mM} \mathrm{NaCl}, 1 \mathrm{mM}$ EDTA, $10 \%$ glycerol, $1 \mathrm{mMDTT}$, and $1 \mathrm{mMPMSF}$. Approximately $20 \mu \mathrm{g}$ extracted proteins were subjected to Western blot analysis. The samples were boiled for $4 \mathrm{~min}$, loaded into $10 \%$ SDSpolyacrylamide gel, resolved by electrophoresis, and then transferred to a nitrocellulose membrane (Bio-Rad). The membrane was placed in PBS containing 4\% nonfat milk powder at room temperature for $1 \mathrm{~h}$ and then washed five times with TPBS at $4{ }^{\circ} \mathrm{C}$. The samples were transferred to PBS containing $4 \%$ nonfat milk powder and incubated with the antibodies for HAT1 (sc-8751), Tip60 (sc-5727), HDAC1 (sc-6298), HDAC2 (sc-7899), Dnmt1 (sc-60B1220), Dnmt3a (sc-20703), Dnmt3b (sc-20704), Dnmt3L (sc-10239), and $\beta$-actin (sc-47778) at $4{ }^{\circ} \mathrm{C}$ for $6 \mathrm{~h}$ respectively. After washing with TPBS, the samples were treated with the secondary antibody in PBS containing $4 \%$ nonfat milk powder at $4{ }^{\circ} \mathrm{C}$ for $1 \mathrm{~h}$. The membrane was washed with TPBS and then developed using the ECL system (Pierce, Rockford, IL, USA) as recommended by the manufacturer's procedure.

\section{Bisulfite sequencing}

DNA methylation states were measured as previously described (Kang et al. 2005). Cells or embryos were lysed in $100 \mu$ l lysis buffer containing $200 \mu \mathrm{g} / \mathrm{ml}$ proteinase K (Rôche Molecular Biochemicals). Then, samples were incubated at $55^{\circ} \mathrm{C}$ for $5 \mathrm{~h}$. Genomic DNA was isolated from bovine embryos using ethanol precipitation method in the presence of $5 \mu \mathrm{g}$ Escherichia coli tRNA as a carrier, and then resuspended in $10 \mu \mathrm{l}$ distilled water. Modification of sample DNA was carried out by adding $235 \mu \mathrm{l}$ freshly made $5 \mathrm{M}$ sodium bisulfite ( $\mathrm{pH} 5$; Sigma) and $13.5 \mu \mathrm{l}$ of $10 \mathrm{mM}$ hydroquinone at $55^{\circ} \mathrm{C}$ for $16 \mathrm{~h}$ in darkness. DNA sample was recovered by DNA purification kit (Bio-Rad) and desulfonated by adding 0.1 volume of $3 \mathrm{M} \mathrm{NaOH}$ and incubated at $37{ }^{\circ} \mathrm{C}$ for $30 \mathrm{~min}$. Satellite I and $\alpha$-satellite DNA sequences were amplified by PCR. Primers and PCR were the same as previously described (Kang et al. 2005). Amplified PCR 
products were inserted into pGEM-T easy vector (Promega) and sequenced by an automatic sequencer (ABI PRISM 377).

\section{Statistical analysis}

All experimental data were analyzed by ANOVA using the SAS package (SAS Inc., Cary, NC, USA). Individual data for the signal intensity of immunostains were pooled in the respective group, and differences among groups were evaluated by least significant difference analysis of one-way ANOVA. Developmental rates of the embryos to blastocysts among experimental groups were analyzed by Duncan's analysis of one-way ANOVA. A value of $P<0.05$ was considered statistically significant.

\section{Acknowledgements}

This work was supported by a grant (sc-2090) from the Stem Cell Research Center of the 21 st Century Frontier Research Program and a grant (2006-04088) from KOSEF funded by MOST, Republic of Korea. The authors declare that there is no conflict of interest that would prejudice the impartiality of this scientific work.

\section{References}

Aoki F, Worrad DM \& Schultz RM 1997 Regulation of transcriptional activity during the first and second cell cycles in the preimplantation mouse embryo. Developmental Biology 181 296-307.

Bourc'his D, Le Bourhis D, Patin D, Niveleau A, Comizzoli P, Renard JP \& Viegas-Pequignot E 2001 Delayed and incomplete reprogramming of chromosome methylation patterns in bovine cloned embryos. Current Biology 11 1542-1546.

Dean W, Santos F, Stojkovic M, Zakhartchenko V, Walter J, Wolf E \& Reik W 2001 Conservation of methylation reprogramming in mammalian development: aberrant reprogramming in cloned embryos. PNAS 98 13734-13738.

Enright BP, Kubota C, Yang X \& Tian XC 2003 Epigenetic characteristics and development of embryos cloned from donor cells treated by trichostatin A or 5-aza-2'-deoxycytidine. Biology of Reproduction 69 896-901.

Finnin MS, Donigian JR \& Pavletich NP 2001 Structure of the histone deacetylase SIRT2. Nature Structural Biology 8 621-625.

Hu JF, Pham J, Dey I, Li T, Vu TH \& Hoffman AR 2000 Allele-specific histone acetylation accompanies genomic imprinting of the insulin-like growth factor II receptor gene. Endocrinology 141 4428-4435.

Imai S, Armstrong CM, Kaeberlein M \& Guarente L 2000 Transcriptional silencing and longevity protein Sir2 is an NAD-dependent histone deacetylase. Nature 403 795-800.

Jones PL, Veenstra GJ, Wade PA, Vermaak D, Kass SU, Landsberger N, Strouboulis J \& Wolffe AP 1998 Methylated DNA, and MeCP2 recruit histone deacetylase to repress transcription. Nature Genetics 19 187-191.

Kang YK, Koo DB, Park JS, Choi YH, Chung AS, Lee KK \& Han YM 2001 Aberrant methylation of donor genome in cloned bovine embryos. Nature Genetics 28 173-177.

Kang YK, Park JS, Koo DB, Choi YH, Kim SU, Lee KK \& Han YM 2002 Limited demethylation leaves mosaic-type methylation states in cloned bovine pre-implantation embryos. EMBO Journal 21 1092-1100.

Kang YK, Lee HJ, Shim JJ, Yeo S, Kim SH, Koo DB, Lee KK, Beyhan Z, First NL \& Han YM 2005 Varied patterns of DNA methylation change between different satellite regions in bovine preimplantation development. Molecular Reproduction and Development 71 29-35.
Kim SH, Kang YK, Koo DB, Kang MJ, Moon SJ, Lee KK \& Han YM 2004 Differential DNA methylation reprogramming of various repetitive sequences in mouse preimplantation embryos. Biochemical and Biophysical Research Communications 324 58-63.

Kishigami S, Mizutani E, Ohta H, Hikichi T, Thuan NV, Wakayama S, Bui HT \& Wakayama T 2006 Significant improvement of mouse cloning technique by treatment with trichostatin $A$ after somatic nuclear transfer. Biochemical and Biophysical Research Communications 340 183-189.

Koo DB, Kang YK, Choi YH, Park JS, Kim HN, Oh KB, Son DS, Park H, Lee KK \& Han YM 2002 Aberrant allocations of inner cell mass and trophectoderm cells in bovine nuclear transfer blastocysts. Biology of Reproduction 67 487-492.

Li E 2002 Chromatin modification and epigenetic reprogramming in mammalian development. Nature Reviews. Genetics 3 662-673.

Mayer W, Niveleau A, Walter J, Fundele R \& Haaf T 2000 Demethylation of the zygotic paternal genome. Nature 403 501-502.

Monk M, Boubelik M \& Lehnert S 1987 Temporal and regional changes in DNA methylation in the embryonic, extraembryonic and germ cell lineages during mouse embryo development. Development 99 371-382.

Nan X, Ng HH, Johnson CA, Laherty CD, Turner BM, Eisenman RN \& Bird A 1998 Transcriptional repression by the methyl-CpG-binding protein MeCP2 involves a histone deacetylase complex. Nature 393 386-389.

Ogonuki N, Inoue K, Yamamoto Y, Noguchi Y, Tanemura K, Suzuki O, Nakayama H, Doi K, Ohtomo Y, Satoh M, et al. 2002 Early death of mice cloned from somatic cells. Nature Genetics 30 253-254.

Peterson CL \& Laniel MA 2004 Histones and histone modifications. Current Biology 14 R546-R551.

Reik W \& Dean W 2001 DNA methylation and mammalian epigenetics. Electrophoresis 22 2838-2843.

Rougier N, Bourc'his D, Gomes DM, Niveleau A, Plachot M, Paldi A \& Viegas-Pequignot E 1998 Chromosome methylation patterns during mammalian preimplantation development. Genes and Development $\mathbf{1 2}$ 2108-2113.

Santos F, Hendrich B, Reik W \& Dean W 2002 Dynamic reprogramming of DNA methylation in the early mouse embryo. Developmental Biology 241 172-182.

Selker EU 1998 Trichostatin A causes selective loss of DNA methylation in Neurospora. PNAS 95 9430-9435.

Shi W \& Haaf T 2002 Aberrant methylation patterns at the two-cell stage as an indicator of early developmental failure. Molecular Reproduction and Development 63 329-334.

Szyf M, Eliasson L, Mann V, Klein G \& Razin A 1985 Cellular and viral DNA hypomethylation associated with induction of Epstein-Barr virus lytic cycle. PNAS 82 8090-8094.

Tamashiro KL, Wakayama T, Akutsu H, Yamazaki Y, Lachey JL, Wortman MD, Seeley RJ, D'Alessio DA, Woods SC, Yanagimachi R, et al. 2002 Cloned mice have an obese phenotype not transmitted to their offspring. Nature Medicine 8 262-267.

Tanaka S, Oda M, Toyoshima Y, Wakayama T, Tanaka M, Yoshida N, Hattori N, Ohgane J, Yanagimachi R \& Shiota K 2001 Placentomegaly in cloned mouse concepti caused by expansion of the spongiotrophoblast layer. Biology of Reproduction 65 1813-1821.

Thompson EM, Legouy E, Christians E \& Renard JP 1995 Progressive maturation of chromatin structure regulates HSP70.1 gene expression in the preimplantation mouse embryo. Development 121 3425-3437.

Wakayama T, Perry AC, Zuccotti M, Johnson KR \& Yanagimachi R 1998 Full-term development of mice from enucleated oocytes injected with cumulus cell nuclei. Nature 394 369-374.

Wee G, Koo DB, Song BS, Kim JS, Kang MJ, Moon SJ, Kang YK, Lee KK \& Han YM 2006 Inheritable histone h4 acetylation of somatic chromatins in cloned embryos. Journal of Biological Chemistry 281 6048-6057.

Wilmut I, Schnieke AE, McWhir J, Kind AJ \& Campbell KH 1997 Viable offspring derived from fetal and adult mammalian cells. Nature $\mathbf{3 8 5}$ 810-813.

Received 11 May 2007

First decision 25 June 2007

Revised manuscript received 24 July 2007

Accepted 31 August 2007 